\title{
PENGGUNAAN KOSAKATA BAHASA INDONESIA PADA GENERASI MILLENIAL
}

\author{
Fernanda Yusi Listeani \\ Program Studi Magister Pendidikan Bahasa Indonesia \\ Universitas Muhammadiyah Prof. DR. Hamka;Jakarta Selatan, 02179184063 \\ fernandamp8@gmail.com
}

\begin{abstract}
Abstrak
Penelitian ini bertujuan mendeskripsikan bentuk makna bahasa millenial ke bahasa Indonesia dari aspek bahasa tulis saat percakapan di group WhatsApp Pramuka Libelta dan Flascheetos. Penelitian dilakukan di SMAN 15 Kabupaten Tangerang kelas XI di bulan Oktober dan November 2019. Metode yang digunakan dalam penelitian ini adalah deskriptif kualitatif. Desain penelitian yang digunakan adalah longitudinal, memperhatikan siswa saat berkomunikasi selama dua bulan. Data dikumpulkan melalui observasi dan angket daring. Data tersebut kemudian diidentifikasi, ditranskripsikan, diamati, dan dianalisis secara empiris. Selanjutnya data yang diperoleh, diklasifikasikan sesuai dengan masalah yang menjadi fokus penelitian. Bahasa Indonesia pada ragam bahasa millenial yang ditemukan dalam percakapan anggota group Pramuka Libelta dan Flascheetos dapat dilihat berdasarkan pola pembentuknya. Hasil pengumpulan data ditemukan 102 kosakata slang/bahasa millenial. 75\% siswa menggunakan 5 kosakata yang paling sering diucapkan seperti; kuy, anjay, ashiyaap, mantaps djiwa, dan mantul. Analisis kosakata slang/bahasa millenial berdasarkan bentuk kata dasar sebanyak 45 kosakata, bentuk frasa sebanyak 34 kosakata, kosakata dengan singkatan sebanyak 13 kosakata, dan kosakata pemenggalan sebanyak 10 kosakata.
\end{abstract}

kata kunci : kosakata, bahasa, generasi millenial

\section{A. PENDAHULUAN}

Bahasa berkembang dan mengabtraksikan pelbagai macam gejala yang muncul di sekitarnya. Bahasa mempunyai peran sangat penting bagi kehidupan. Bahasa merupakan komponen terpenting dalam kehidupan manusia. Manusia tidak bisa melanjutkan kelangsungan hidup tanpa adanya bahasa. Bahasa Indonesia merupakan bahasa pemersatu sesuai dengan isi sumpah pemuda ke-3. Bahasa Indonesia digunakan sebagai sarana komunikasi pada setiap kegiatan, seperti dalam bidang kebudayaan, ilmu pengetahuan dan teknologi. Perkembangan seni, budaya, ilmu pengetahuan dan teknologi tidak lepas dari kemajuan teknologi yang memudahkan masyarakat untuk mengakses informasi.

Era globalisasi saat ini, penggunaan bahasa sebagai media komunikasi sangat terpengaruh oleh perkembangan teknlogi dan informasi. Terdapat faktor yang mempengaruhi bahasa yaitu berkembangnya teknologi dan informasi yang sangat cepat menyebar. Sehingga informasi positif atau negatif mudah diperoleh. Ragam bahasa yang sering digunakan saat ini ragam bahasa santai dan akrab. Slang merupakan salah satu 
bahasa yang diciptakan oleh suatu kelompok/generasi yang digunakan untuk berkomunikasi dan diketahui oleh kelompok tersebut. Sependapat dengan Chaer dan Agustina (2010:67) slang merupakan ragam bahasa variasi sosial yang bersifat khusus dan rahasia. Variasi bahasa yang gunakan pada generasi tertentu hanya dipahami oleh generasi tersebut.

Slang dianggap ragam bahasa yang akrab karena gaya ujaran dicirikan dengan menggunakan kode bahasa yang bersifat pribadi dan digunakan dalam sebuah kelompok atau generasi. Bahasa slang tidak memerlukan tata bahasa yang lengkap dengan artikulasi yang jelas tetapi cukup dengan mengucapkan singkatan atau akronim dari kosakata karena adanya pemahaman makna kosakata dalam kelompok tersebut.

Era millennial ialah masa adanya peningkatan penggunaan dan keakraban dengan komunikasi, media dan teknologi digital seperti saat ini. Kemampuan berbahasa sering menekan pada pengetahuan kebahasaan sehingga berpengaruh dengan penguaasan kosakata. Kosakata merupakan unsur yang penting dalam kegiatan berbahasa yang berkenan dengan penyampaian ide atau gagasan. Saat seseorang menguasai perbendaharaan kosakata, maka semakin banyak ide atau gagasan yang akan dikuasainya sehingga mudah untuk diungkapkan (Keraf,2010:21).

Generasi alfa memiliki karakter yang khas. Mereka menggunakan gawai dan menjadikan internet sebagai kebutuhan pokok. Generasi ini lahir antara tahun 2000 sampai saat ini. Mereka cendrung menggunakan ragam bahasa akrab ketika berkomunikasi langsung maupun secara daring di media sosial. Mereka menganggap bahwa bahasa slang merupakan bahasa millenial karena semua anak yang lahir pada tahun 2000an memahami makna yang dimaksud antara penutur dengan lawan tuturnya. Generasi milenial yang lebih dengan teknologi akan selalu menghubungkan segala hal dalam dunia digital. Pada era digital sekarang ini, pemerintah dan masyarakat sangat perlu melakukan perencanaan bahasa Indonesia (Language Planning) agar tidak menggerus bahasa daerah dan tidak tergerus oleh bahasa asing.

Penggunaan bahasa millenial bisa berkomunikasi secara langsung dan dapat dilakukan saat mengirim pesan kepada lawan tutur melalui media sosial secara daring. Pada media sosial, penggunanya mudah mengakses semua informasi, berpartisipasi, berbagi dan menciptakan sebuah kosakata baru. Dalam penelitian ini, data diambil dari media sosial group WhatsApp (organisasi dan kelas) siswa-siswi kelas XI dengan usia antara 16 sampai 17 tahun. Pramuka Libelta dan Flascheetos adalah sebuah organisasi sekolah yang ada di SMAN 15 Kabupaten Tangerang. Perkumpulan ini dijadikan media untuk siswa berkomunikasi, menjalin silaturahmi dan mengadakan kegiatan. 
Bahasa yang digunakan pada group WhatsApp bisa dikategorikan sebagai bahasa millenial karena bahasa yang digunakan berupa kosakata yang disingkat, kosakata yang digabung menjadi akronim, kosakata yang dibalik, kosakata dari sebuah peristiwa atau plesetan. Kosakata dalam bahasa millenial bisanya memiliki ciri-ciri, kosakata tersebut belum diketahui oleh masyarakat karena bukan kosakata pada umumnya dan makna dari kosakata tersebut sulit untuk ditebak.

Pada bahasa Indonesia banyak bahasa slang yang digunakan oleh generasi millenial. Seperti "anjay boljug tuh" yang bermakna waw, boleh juga itu. "lau dimans? Sokin lah bree" yang bermakna kamu sedang dimana? Sini lah bro (sebutan untuk laki-laki). Dari beberapa contoh tersebut maka peneliti akan menganalisis makna dari kosakata yang dibentuk oleh generasi millenial tersebut.

Penelitian bahasa millenial cukup banyak dilakukan peneliti lainnya, seperti penelitian Pengaruh Media Sosial dan Eksistensi Bahasa Indonesia di Era Milenial yang dilakukan oleh Fullaikhah Anjani dari FKIP Universitas Sebelas Maret Surakarta. Penelitiannya terkait dengan penggunaan bahasa dalam media sosial khsusnya Instagram di era millenial yang mempengaruhi eksistensi bahasa Indonesia. Pada akun instagram @cilacap_kekinian, bahasa yang digunakan merupakan usaha admin untuk memperkenalkan dan mengembangkan dialek Ngapak agar tidak memudar di era milenial.

Selain itu, penelitian Nimas Permata Putri dari STKIP PGRI Pacitan tentang Eksistensi Bahasa Indonesia pada Generasi Millenial. Penelitiannya terkait dengan penggunaan bahasa Indonesia dengan kajian sosiolinguistik secara kualitatif. Hasilnya diperoleh siwa SMK Harapan Sukoharjo Jurusan Teknik Elektronika Industri dan mahasiswa STKIP PGRI Pacitan Prodi Pendidikan Bahasa dan Sastra Indonesia tidak semunya mengetahui padanan kosakata asing dalam bahasa Indonesia.

Artikel ini membahas khususnya aspek penggunaan kosakata bahasa Indonesia pada generasi millenial di SMAN 15 Kabupaten Tangerang Tahun Pelajaran 2019/2020. Ketika siswa-siswi bercakap banyak kosakata yang tidak ada maknanya pada KBBI. Berdasarkan uraian di atas, artikel ini mendeskripsikan penggunaan kosakata bahasa Indonesia pada generasi millenial. Masalah tersebut dibatasi pada hal-hal berikut : Penggunaan kosakata bahasa Indonesia yang diucapkan siswa-siswi sesuai dengan kaidah bahasa Indonesia, Adakah faktor sosial budaya yang mempengaruhinya kosakata yang digunakan pada generasi millenial dan cara penggunaan kosakata bahasa Indonesia pada siswa kelas XI SMAN 15 Kabupaten Tangerang Tahun Pelajaran 2019/2020. 


\section{B. KAJIAN TEORI}

Penguasaan kosakata merupakan kemampuan yang dimiliki seseorang untuk menguasai perbendaharaan kata dalam bahasa yang sesuai dengan maknanya. Ketika seseorang menguasai perbendaharaan kosakata maka akan lebih mudah berinteraksi dengan orang lain. Kemampuan memahami makna kata dan menggunkan kosakata didasari oleh diri sendiri. Soedjito dan Saryono (2011:3) mendefinisikan bahwa kosakata merupakan perbendaharaan kata yang dimiliki oleh suatu bahasa. Kosakata dari luar bahasa tersebut bisa memberikan sumbangan untuk perbendaharaan kosakata. Hubungan bahasa Indonesia dengan bahasa daerah dan bahasa asing dapat memperkaya kosakata bahasa Indonesia. Kata merupakan satuan bentuk terkecil dari kalimat yang bisa berdiri sendiri dan mempunyai makna. Hal ini sependapat dengan Chaer (2007:9) kosakata merupakan bentuk yang mempunyai susunan fonologi yang tetap atau stabil. Penguasaan kosakata dapat diartikan kemampuan menguasai, memahami atau menggunakan kata yang terdapat dalam suatu bahasa, baik ragam bahasa lisan atau ragam bahasa tulis.

Ragam bahasa jika ditinjau dari media atau sarana yang digunakan untuk menghasilkan bahasa dapat dibedakan menjadi dua yaitu ragam bahasa lisan dan ragam bahasa tulis. Ragam bahasa lisan merupakan ragam bahasa yang dikeluarkan oleh alat ucap. Sedangkan ragam bahasa tulis merupakan ragam bahasa yang diproduksi dengan tulisan berupa huruf dan unsur lainnya. Hal ini pun senada dengan Sugono (2009:16) Ragam bahasa lisan mencakup aspek lafal, tata bahasa berupa kata/susunan kalimat dan kosakata. Pada ragam bahasa lisan, penutur bisa mengekspresikan kepemahaman ide, gagasan, pengalaman, sikap dan rasa. Sedangkan Ragam bahasa tulis memproduksi kata melalui tata cara penulisan. Ragam bahasa ini mencakup tata bahasa kosakata dan ejaan. Ragam bahasa tulis ekspresi tidak bisa diungkapkan atau digambarkan pada tulisan. Oleh karena itu, ragam bahasa tulis dituntut adanya kelengkapan unsur tata bahasa.

Bahasa dipengaruhi oleh kebudayaan masyarakat sehingga segala hal yang berkaitan dengan kebudayaan akan tercermin dalam bahasa. Bahasa sangat mempengaruhi cara berfikir manusia. Sehingga, tidak bisa lepas karena bahasa merupakan hasil budaya suatu masyarakat yang kompleks dan aktif. Bahasa merupakan aspek terpenting dalam mempelajari suatu kehidupan dan kebudayaan masyarakat. Kebudayaan mengatur interaksi manusia di dalam masyarakat, maka kebahasaan merupakan sistem yang berfungsi sebagai sarana interaksi. 
Bahasa adalah alat komunikasi utama dengan bahasa manusia dapat mengungkapkan pikiran dan perasaan kepada orang lain. Bahasa memungkinkan membangun kebudayaan serta menguasai ilmu pengetahuan. Sehingga hubungan antara bahasa dan masyarakat tercerminkan pola yang bersifat koordinatif dan subordinatif. Oleh karena itu, ketika seseorang mempelajari bahasa maka ia akan mempelajari kebudayaan melalui bahasa. Bahasa merupakan produk masyarakat untuk menyampaikan kebudayaan dari masyarakat. Senada dengan Brown (2008: 206) berpendapat budaya merupakan gagasan, kebiasaan, keterampilan, seni yang mencirikan sekelompok orang dalam sebuah priode tertentu.Penggunaan bahasa oleh penutur bukan secara acak, melainkan harus mempertimbangkan beberapa faktor, antara lain siapa yang berbicara, siapa lawan bicaranya, topik apa yang sedang dibicarakan dan di mana peristiwa tutur itu terjadi.

Saat seseorang berkomunikasi, masing-masing individu mengadakan interaksi tersebut yang diwujudkan dalam tindak tutur dan gerak tubuh. Tindak tutur dalam suatu interaksi terkadang dapat mengundang kemarahan, ketertekanan, ketakutan, ketidaknyamanan, dan kecemasan yang diwujudkan dengan berbagai cara. Emosi merujuk pada suatu perasaan dan pikiran yang khas, suatu keadaan biologis dan psikologis dan serangkaian kecendrungan bertindak (Goleman, 1998:409). Goleman mengkelompokkan emosi dalam golongan besar yaitu: Amarah (mengamuk, benci, marah, jengkel, kesal hati, tersinggung), Kesedihan (sedih, muram, kesepian, putus asa, depresi), Rasa takut (cemas, takut, gugup, khawatir, tidak tenang), kenikmatan (bahagia, gembira, puas, riang, takjub), cinta (penerimaan, persahabtan, kepercayaan, bakti, hormat, kasmaran), terkejut (terkejut, tersikap, takjub, terpana), jengkel (hina, jijik, muak, mual, benci), dan malu (rasa salah, malu hati, kesal, sesal, hina, aib).

Undang-Undang Dasar 1945 pasal 36 mengamanahkan bahwa bahasa Indonesia berfungsi sebagai bahasa resmi kenegaraan, pengantar pendidikan dan sarana pengembangan dan pemanfaatan ilmu pengetahuan, teknologi, seni serta bahasa media massa. Namun, dalam kenyataannya penggunaan bahasa Indonesia berbanding terbalik karena adanya unsur penggunaan selain bahasa Indonesia atau Ivan Lanin (2019:33) menyebutnya dengan xenoglosofilia. Xenoglosofilia merupakan fenomena kecendrungan menggunakan kosakata yang aneh dan asing.

Berdasarkan fenomena xenoglosofilia pada siswa-siswi kelas XI SMAN 15 Kabupaten Tangerang Tahun Pelajaran 2019/2020 maka kajian penelitian ini adalah Berdasarkan fenomena xenoglosofilia pada siswa-siswi kelas XI SMAN 15 Kabupaten Tangerang Tahun Pelajaran 2019/2020 maka kajian penelitian ini adalah penggunaan 
bahasa millenial secara tidak langsung melalui media sosial secara daring. Pada media sosial group WhatsApp (organisasi dan kelas) siswa-siswi kelas XI dengan usia antara 16 sampai 17 tahun. Pramuka Libelta dan Flascheetos adalah sebuah organisasi sekolah yang ada di SMAN 15 Kabupaten Tangerang.

\section{METODE PENELITIAN}

Metode yang digunakan dalam penelitian ini adalah metode deskriptif kualitatif . Metode deskriptif kualitatif ini akan mendeskripsikan penggunaan kosakata bahasa Indonesia pada group WhatsApp (Pramuka Libelta dan Flascheetos) siswa-siswi kelas XI. Artikel ini bertujuan untuk mendeskripsikan bentuk serta arti dari bahasa millenial ke dalam bahasa Indonesia. Desain penelitian yang digunakan adalah longitudinal, yaitu memperhatikan siswa saat berkomunikasi dengan kawan sebayanya selama 2 bulan.

Sumber data utama artikel ini adalah tuturan langsung maupun tidak langsung yang dianggap sebagai bahasa millenial pada bahasa Indonesia. Tuturan tersebut tersedia dalam bentuk tulisan percakapan dalam kolom chatting group WhatsApp (Pramuka Libelta dan Flascheetos). Data ini dikumpulkan selama dua bulan melalui observasi dan angket daring. Data tersebut kemudian diidentifikasi, dianalisis ditranskripsikan, lalu diamati dan dianalisis secara empiris. Selanjutnya data yang sudah diperoleh, diklasifikasikan sesuai dengan masalah yang menjadi fokus penelitian.

Pada saat siswa berkomunikasi dengan kawannya dan mengeluarkan istilah-istilah asing (tidak sesuai dengan bahasa Indonesia). Kosakata tersebut hanya biasa dipahami dan digunakan oleh generasi millenial maka data yang sudah diperoleh, diklasifikasikan berdasarkan kosakata yang disingkat, kosakata yang digabung menjadi akronim, kosakata yang dibalik, kosakata dari sebuah peristiwa atau plesetan. Serta dikaitkan dengan pandangan para ahli yang menyatakan bahwa bahasa jika ditinjau dari media atau sarana yang digunakan untuk menghasilkan bahasa berbeda.

\section{HASIL DAN PEMBAHASAN}

Bahasa Indonesia pada ragam bahasa millenial yang ditemukan dalam percakapan para anggota group Pramuka Libelta dan Flascheetos dapat dilihat berdasarkan pola pembentuknya. Hasil pengumpulan data ditemukan 102 kosakata slang atau bahasa millenial. Analisis kosakata slang/bahasa millenial ini berdasarkan bentuk kata dasar, 
bentuk frasa, kosakata dengan singkatan, dan kosakata dengan pemenggalan. Berikut tabel hasil analisis kosakata bahasa millenial berdasarkan pemakaiannya.

Tabel 1 Perubahan struktur fonologi bentuk kata dasar

\begin{tabular}{|c|c|c|c|}
\hline \multirow[t]{2}{*}{ No. } & \multirow[t]{2}{*}{ Kosakata } & \multicolumn{2}{|c|}{ Keterangan } \\
\hline & & $\begin{array}{c}\text { Kosakata } \\
\text { Bahasa } \\
\text { Indonesia }\end{array}$ & $\begin{array}{c}\text { Makna dan } \\
\text { Pemakaiannya }\end{array}$ \\
\hline 1. & ucul & lucu & $\begin{array}{l}\text { lucu } \\
\text { "uch ucul beed } \\
\text { dah" }\end{array}$ \\
\hline 2. & Kuy & yuk & $\begin{array}{l}\text { yuk } \\
\text { "kuy lah" }\end{array}$ \\
\hline 3. & Skuy & yuk & $\begin{array}{l}\text { yuk } \\
\text { "skuy main" }\end{array}$ \\
\hline 4. & Eug & saya & $\begin{array}{l}\text { Gue } \\
\text { "eug pergi yee" }\end{array}$ \\
\hline 5. & Lau & kamu & $\begin{array}{l}\text { Lu } \\
\text { "lau tadi kemana } \\
\text { bree" }\end{array}$ \\
\hline 6. & Sans & santai & $\begin{array}{l}\text { Santai } \\
\text { "yaelah sans aja } \\
\text { kali"" }\end{array}$ \\
\hline 7. & Sampis & sampah & $\begin{array}{l}\text { sampah } \\
\text { "bau sampis di } \\
\text { kelas" }\end{array}$ \\
\hline 8. & Nongki & nongkrong & $\begin{array}{l}\text { nongkrong bareng } \\
\text { "nongki dimana } \\
\text { nih?" }\end{array}$ \\
\hline 9. & Ens & enak & $\begin{array}{l}\text { Enak } \\
\text { "janji jiwa ens loh } \\
\text { gais" }\end{array}$ \\
\hline 10. & Bais & habis & $\begin{array}{l}\text { Abis } \\
\text { "isi sepidol bais!" }\end{array}$ \\
\hline 11. & Cotba & $\begin{array}{l}\text { banyak } \\
\text { omong }\end{array}$ & $\begin{array}{l}\text { banyak omong } \\
\text { "halah cotba lau!" }\end{array}$ \\
\hline 12. & Lobeh & boleh & $\begin{array}{l}\text { Boleh } \\
\text { "lobeh gak nih?" }\end{array}$ \\
\hline 13. & Sabi & bisa & $\begin{array}{l}\text { Bisa } \\
\text { "sabi ya nanti } \\
\text { malem" }\end{array}$ \\
\hline 14. & Saik & asik & $\begin{array}{l}\text { Asik } \\
\text { "saik buka di } \\
\text { rumah bu nanda" }\end{array}$ \\
\hline 15. & Suping & pusing & $\begin{array}{l}\text { Pusing } \\
\text { "rara suping } \\
\text { anterin ke uks" }\end{array}$ \\
\hline 16. & Beuud & banget & $\begin{array}{l}\text { Banget } \\
\text { "lagi bt beuud" }\end{array}$ \\
\hline 17. & Boci & tidur siang & $\begin{array}{l}\text { bobo ciang } \\
\text { "akhirnya bisa }\end{array}$ \\
\hline
\end{tabular}




\begin{tabular}{|c|c|c|c|}
\hline & & & boci nih" \\
\hline 18. & Obob & tidur & $\begin{array}{l}\text { Bobo } \\
\text { "weh } \\
\text { sonoh" obob }\end{array}$ \\
\hline 19. & Gemay & gemas & $\begin{array}{l}\text { Gemas } \\
\text { "ih gemay beeud } \\
\text { dah" }\end{array}$ \\
\hline 20. & Misquen & miskin & $\begin{array}{l}\text { Miskin } \\
\text { "misquen kuota } \\
\text { yaa?" }\end{array}$ \\
\hline 21. & Caw & berangkat & $\begin{array}{l}\text { Berangkat } \\
\text { "caw ya!" }\end{array}$ \\
\hline 22. & Zheyeng & sayang & $\begin{array}{l}\text { Sayang } \\
\text { "kemana } \\
\text { zheyeng?" aja }\end{array}$ \\
\hline 23. & Rempong & rumit & $\begin{array}{l}\text { Rumit } \\
\text { "rempong amat } \\
\text { dah" }\end{array}$ \\
\hline 24. & Gengges & menganggu & $\begin{array}{l}\text { Ganggu } \\
\text { "gengges lau" }\end{array}$ \\
\hline 25. & Kicep & terdiam & $\begin{array}{l}\text { Diam } \\
\text { "kicep kan?" }\end{array}$ \\
\hline 26. & Kongkow & $\begin{array}{l}\text { kumpul } \\
\text { bareng }\end{array}$ & $\begin{array}{l}\text { kumpul } \\
\text { "kongkow } \\
\text { lusa" }\end{array}$ \\
\hline 27. & Dae & ada & $\begin{array}{l}\text { Ada } \\
\text { "dae dae aje" }\end{array}$ \\
\hline 28. & lebeh & berlebihan & $\begin{array}{l}\text { Berlebihan } \\
\text { "gausah lebeh } \\
\text { deh" }\end{array}$ \\
\hline 29. & Takol & melempar & $\begin{array}{l}\text { Timpuk } \\
\text { "yee w takol nih" }\end{array}$ \\
\hline 30. & Jiper & takut & $\begin{array}{l}\text { Takut } \\
\text { "lah jadi jiper } \\
\text { gini", }\end{array}$ \\
\hline 31. & Goks & gila & $\begin{array}{l}\text { Gila } \\
\text { "goks dah lau" }\end{array}$ \\
\hline 32. & Kalem & tenang & $\begin{array}{l}\text { tenang } \\
\text { "kalem aja ya" }\end{array}$ \\
\hline 33. & Santuy & santai & $\begin{array}{l}\text { santai } \\
\text { "santuy aja" }\end{array}$ \\
\hline 34. & Squad & $\begin{array}{l}\text { kelompok/ } \\
\text { komunitas }\end{array}$ & $\begin{array}{l}\text { kelompok/ } \\
\text { komunitas } \\
\text { "flascheetos } \\
\text { squad" }\end{array}$ \\
\hline 35. & Tsadeest & sadis & $\begin{array}{l}\text { sadis } \\
\text { "tsadeest prnya" }\end{array}$ \\
\hline 36. & Unfaedah & $\begin{array}{l}\text { tidak } \\
\text { bermanfa } \\
\text { at }\end{array}$ & $\begin{array}{l}\text { tidak bermanfaat } \\
\text { "obrolan } \\
\text { unfaedah ya" }\end{array}$ \\
\hline 37. & Receh & murahan & $\begin{array}{l}\text { murahan } \\
\text { "receh beeud ya" }\end{array}$ \\
\hline 38. & Nitijen & warga net & $\begin{array}{l}\text { warga net } \\
\text { "banyak }\end{array}$ \\
\hline
\end{tabular}




\begin{tabular}{|c|c|c|c|}
\hline & & & nitijennya" \\
\hline 39. & Bucin & posesif & $\begin{array}{l}\text { budak cinta } \\
\text { "bucin ya!" }\end{array}$ \\
\hline 40. & Maaciww & $\begin{array}{r}\text { terima } \\
\text { kasih }\end{array}$ & $\begin{array}{l}\text { terima kasih } \\
\text { "maaciww ya" }\end{array}$ \\
\hline 41. & $\begin{array}{l}\text { Cemungu } \\
\mathrm{dh}\end{array}$ & semangat & $\begin{array}{l}\text { semangat } \\
\text { "cemungudh" }\end{array}$ \\
\hline 42. & $\begin{array}{l}\text { Cemboku } \\
\mathrm{r}\end{array}$ & cemburu & $\begin{array}{l}\text { cemburu } \\
\text { “cembokur ye?" }\end{array}$ \\
\hline 43. & Hadeh & haduh & $\begin{array}{l}\text { haduh } \\
\text { "hadeh... pr lagi } \\
\text { ya?" }\end{array}$ \\
\hline 44. & Tercyduk & terciduk & $\begin{array}{l}\text { terciduk } \\
\text { " lau tercyduk } \\
\text { nyontek ya?" }\end{array}$ \\
\hline 45. & Ashiyaap & siap & $\begin{array}{l}\text { Siap } \\
\text { "Ashiyaap bu." }\end{array}$ \\
\hline
\end{tabular}

Kosakata dari struktur perubahan struktur fonologis dari bentuk kata dasar terdiri atas susunan balik, ambil suku dan ubah total. Kosakata susun balik dengan 11 kosakata ucul, kuy,sabi, saik, misquen, santuy, cemungudh, cembokur, hadeh, tercyduk, cotba dan ashiyaap. Susunan balik ini terdapat stuktur suku kata yang dibalik seperti uculmempunyai dasar kosakata bahasa Indonesia lиси menjadi ucul. Kosakata ini digunakan saat percakapan pada teman sebaya. Kosakata ambil suku kata dengan 25 kosakata eug, lau, sampis, lobeh, suping, boci, obob, caw, rempong, gengges, kicep, kongkow, dae, lebeh takol, kalem, goks, jiper, takol, squad, unfaedah, receh, nitijen, bucin, dan maaciww. Susunan ambil suku kata seperti eug berawal dari kosakata gue menjadi eug dalam bahasa Indonesia bermakna saya. Suku kata pertama digunakan dan ditambahkan untuk pengucapannya seperti sampis mempunyai kata awal sampah menjadi sampis karena penggunaan suku kata sam dan ditambahkan suku kata pis menjadi sampis yang bermakna sampah. Dan kosakata ubah total dengan 9 kosakata beuud, gemay, zheyeng, tsadeest, unfaedah, receh, bucin, dan squad. Kosakata ubah total terdapat perubahan stuktur kosakata yang sangat singifikan sepertigemay berawal dari kosakata gemas menjadi gamay dalam bahasa Indonesia bermakna sangat jengkel atau sangat suka cita bercampur jengkel. Kosakata ini digunakan saat percakapan.

Berdasarkan penggunaan emosialnya pada bentuk struktur fonologis kata dasar mempunyai 2 kosakata yang menunjukkan amarah, 5 kosakata yang menunjukkan rasa takut, 17 kosakata yang menunjukkan kenikmatan, 6 kosakata menunjukan cinta, 5 kosakata menunjukan terkejut, 9 kosakata menujukkan kejengkelan, 1 kosakata menunjukkan malu, tetapi belum ditemui kosakata kesedihan pada bentuk struktur fonologis kata dasar.

Tabel 2 Berbentuk Frasa

\begin{tabular}{|llll|} 
No. Kosakata & \multicolumn{2}{c}{ Keterangan } \\
\cline { 3 - 4 } & & $\begin{array}{c}\text { Kosakata } \\
\text { Bahasa } \\
\text { Indonesia }\end{array}$ & $\begin{array}{l}\text { Makna dan } \\
\text { Pemakaiannya }\end{array}$ \\
\hline 1. & Dimans & di mana & $\begin{array}{l}\text { di mana } \\
\text { "weh, dimans?" } \\
\text { Padahal } \\
\text { "dahal mah }\end{array}$ \\
\hline 2. & dahal & Padahal &
\end{tabular}




\begin{tabular}{|c|c|c|c|}
\hline & & & makan aja" \\
\hline 3. & Yauds & ya sudah & $\begin{array}{l}\text { ya sudah } \\
\text { "yauds lah yaa" }\end{array}$ \\
\hline 4. & Kemans & ke mana & $\begin{array}{l}\text { ke mana } \\
\text { "pada kemans } \\
\text { nih?" }\end{array}$ \\
\hline 5. & Duls & Dahulu & $\begin{array}{l}\text { Dahulu } \\
\text { "lau ke alfa duls } \\
\text { ya" }\end{array}$ \\
\hline 6. & Gimans & Bagaimana & $\begin{array}{l}\text { Bagaimana } \\
\text { "jadinya gimans } \\
\text { gais?" }\end{array}$ \\
\hline 7. & Kopgap & $\begin{array}{l}\text { pertemuan } \\
\text { secara }\end{array}$ & $\begin{array}{l}\text { kopi darat } \\
\text { gabungan }\end{array}$ \\
\hline & & gabungan & $\begin{array}{ccc}\text { "bu, } & \text { kopgap } \\
\text { sama } & \text { ipa } & 1 \\
\text { ya?" } & & \end{array}$ \\
\hline 8. & gudnyus & berita baik & $\begin{array}{l}\text { good news } \\
\text { "ada gudnyus } \\
\text { nih besok } \\
\text { liboor" }\end{array}$ \\
\hline 9. & Mantul & mantap betul & $\begin{array}{l}\text { mantap betul } \\
\text { "mantul gan" }\end{array}$ \\
\hline 10. & Anjay & $\begin{array}{l}\text { ungkapan } \\
\text { kekaguman }\end{array}$ & $\begin{array}{l}\text { Keren } \\
\text { "anjay juga lau" }\end{array}$ \\
\hline 11. & Tikum & titik berkumpul & $\begin{array}{l}\text { titik kumpul } \\
\text { "tikum di rumah } \\
\text { ya" }\end{array}$ \\
\hline 12. & Gretong & Gratis & $\begin{array}{l}\text { Gratis } \\
\text { "w mau } \mathrm{kl} \\
\text { gretong" }\end{array}$ \\
\hline 13. & Boljug & boleh juga & $\begin{array}{l}\text { boleh juga } \\
\text { "boljug tuh" }\end{array}$ \\
\hline 14. & Ngocol & songong & $\begin{array}{l}\text { Songong } \\
\text { "ngocol beeud } \\
\text { tuh anak" }\end{array}$ \\
\hline 15. & Bokis & Bohong & $\begin{array}{l}\text { Bohong } \\
\text { "bokis aja lau" }\end{array}$ \\
\hline 16. & Lenjeh & Centil & $\begin{array}{l}\text { Centil } \\
\text { "dianya lenjeh } \\
\text { bu" }\end{array}$ \\
\hline 17. & Purik & Pelit & $\begin{array}{l}\text { Pelit } \\
\text { "jan purik lau" }\end{array}$ \\
\hline 18. & Gas & $\begin{array}{l}\text { ungkapan } \\
\text { kekesalan }\end{array}$ & $\begin{array}{l}\text { ungkapan } \\
\text { kekesalan } \\
\text { "jan ngegas } \\
\text { dong" }\end{array}$ \\
\hline 19 & Kompor & & "kompor lau" \\
\hline 20. & Bokek & tidak ada uang & $\begin{array}{l}\text { tidak ada uang } \\
\text { "lagi bokek w", }\end{array}$ \\
\hline 21. & Palbis & paling bisa & $\begin{array}{l}\text { paling bisa } \\
\text { "emang } \\
\text { palbis" dah }\end{array}$ \\
\hline 22. & Salting & salah tingkah & salah tingkah \\
\hline
\end{tabular}




\begin{tabular}{|c|c|c|c|}
\hline & & & "salting kan?" \\
\hline 23. & Kilik & $\begin{array}{l}\text { uji } \\
\text { kekompakan }\end{array}$ & $\begin{array}{l}\text { tos kekompakan } \\
\text { "jangan lupa } \\
\text { nanti kilik di } \\
\text { lapangan" }\end{array}$ \\
\hline 24. & Pelakor & $\begin{array}{l}\text { perebut } \\
\text { pasangan }\end{array}$ & $\begin{array}{l}\text { perbut laki orang } \\
\text { "bu, dia } \\
\text { pelakor!" }\end{array}$ \\
\hline 25. & Bosque & Bosku & $\begin{array}{l}\text { Bosku } \\
\text { "siap bosque" }\end{array}$ \\
\hline 26 & Керо & ingin tahu & $\begin{array}{l}\text { ingin tahu } \\
\text { "kepo ya?" }\end{array}$ \\
\hline 27. & Mager & $\begin{array}{l}\text { malas } \\
\text { berpindah }\end{array}$ & $\begin{array}{l}\text { malas gerak } \\
\text { "mager nih" }\end{array}$ \\
\hline 28. & Sotoy & sok tahu & $\begin{array}{l}\text { sok tahu } \\
\text { "sotoy!" }\end{array}$ \\
\hline 29. & Modus & modal dusta & $\begin{array}{l}\text { modal dusta } \\
\text { "dia modus aja" }\end{array}$ \\
\hline 30. & Gais & Kawan & $\begin{array}{l}\text { kawan } \\
\text { "gais dimana?" }\end{array}$ \\
\hline 31. & $\begin{array}{l}\text { mantaps } \\
\text { djiwa/ } \\
\text { mantapp } \\
\text { u jiwa }\end{array}$ & Keren & $\begin{array}{l}\text { Keren } \\
\text { "mantaps djiwa } \\
\text { gais" }\end{array}$ \\
\hline 32. & Hoax & berita palsu & $\begin{array}{l}\text { berita palsu } \\
\text { "hoax aja lau" }\end{array}$ \\
\hline 33. & Bonyok & orang tua & $\begin{array}{l}\text { orang tua } \\
\text { "jan lupa izin } \\
\text { bonyok" }\end{array}$ \\
\hline 34. & $\begin{array}{l}\text { ceble/ } \\
\text { calang }\end{array}$ & umpatan kasar & $\begin{array}{l}\text { umpatan kasar } \\
\text { "dasar ceble" }\end{array}$ \\
\hline
\end{tabular}

Tiga puluh empat kosakata tersebut terbentuk karena berbentuk frasa seperti bonyok berasal dari kata orang dan tua jika digabungkan menjadi orang tua yang mempunyai makna orang yang dianggap tua atau ayah,ibu kandung. Pemakaian kosakata ini untuk menyebutkan ayah dan ibu kandung. Bosque berasal dari kata bos dan aku jika digabungkan menjadi bosku mempunyai makna jabatan yang memiliki pangkat lebih tinggi atau atasan saya. Pemakaian kosakata ini untuk memanggil kawan yang dianggap lebih tua dan disegani pada teman sebayanya. Modus berasal dari frasa modal dan dusta, jika digabungkan menjadi modus mempunyai makna dasar dan dusta bermakna tidak benar jika digabungkan modus mempunyai makna hanya berlandaskan ketidak benaran (dusta). Kosakata ini digunakan untuk merayu lawan jenis atau meminta bantuan kepada teman. Berdasarkan penggunaan emosialnya pada bentuk struktur fonologis berbentuk frasa mempunyai 2 kata yang menunjukkan amarah, 1 kata menunjukkan kesedihan, 2 kata menujukkan rasa takut, 12 kata 
menunjukkan kenikmatan, 3 kata menujukkan cinta, dua kata menujukkan terkejut, 10 kata menunjukkan jengkel, dan 2 kata menunjukkan malu.

Tabel 3 Kosakata dengan Singkatan

\begin{tabular}{|c|c|c|c|}
\hline \multirow[t]{2}{*}{ No. } & \multirow[t]{2}{*}{ Kosakata } & \multicolumn{2}{|c|}{ Keterangan } \\
\hline & & $\begin{array}{c}\text { Kosakata } \\
\text { Bahasa } \\
\text { Indonesia }\end{array}$ & $\begin{array}{c}\text { Makna dan } \\
\text { Pemakaiannya }\end{array}$ \\
\hline 1. & TP & $\begin{array}{l}\text { mencari } \\
\text { perhatian }\end{array}$ & $\begin{array}{l}\text { tebar pesona } \\
\text { "tp bangget ya lau" }\end{array}$ \\
\hline 2. & $\mathrm{GC}$ & $\begin{array}{l}\text { bergerak } \\
\text { cepat }\end{array}$ & $\begin{array}{l}\text { gerak cepat } \\
\text { "woy gc napa" }\end{array}$ \\
\hline 3. & $\mathrm{BM}$ & $\begin{array}{l}\text { banyak } \\
\text { mau }\end{array}$ & $\begin{array}{l}\text { banyak mau } \\
\text { "duh bm beuud } \\
\text { kan?" }\end{array}$ \\
\hline 4. & JB & $\begin{array}{l}\text { bergabung } \\
\text { dengan } \\
\text { teman- } \\
\text { teman }\end{array}$ & $\begin{array}{l}\text { join bareng } \\
\text { "jb sama anak pmr } \\
\text { ya?" }\end{array}$ \\
\hline 5. & WTF & $\begin{array}{l}\text { umpatan } \\
\text { kasar }\end{array}$ & $\begin{array}{l}\text { what the fuck! } \\
\text { (sialan) } \\
\text { "wtf lu!" }\end{array}$ \\
\hline 6. & BT & Bosan & $\begin{array}{l}\text { broken time } \\
\text { "bt gue!" }\end{array}$ \\
\hline 7. & BTW & $\begin{array}{l}\text { ngomong- } \\
\text { ngomong }\end{array}$ & $\begin{array}{l}\text { by the way } \\
\text { "btw pada apa?" }\end{array}$ \\
\hline 8. & FWB & $\begin{array}{l}\text { teman tapi } \\
\text { mesra }\end{array}$ & $\begin{array}{l}\text { friend with benefith } \\
\text { "lau sama dia fwb } \\
\text { ya?" }\end{array}$ \\
\hline 9. & VN & pesan suara & $\begin{array}{l}\text { voice note } \\
\text { "weh jangan vn } \\
\text { dong" }\end{array}$ \\
\hline 10. & VC & $\begin{array}{l}\text { panggilan } \\
\text { video }\end{array}$ & $\begin{array}{l}\text { video call } \\
\text { "vc ya bu" }\end{array}$ \\
\hline 11. & HTS & $\begin{array}{l}\text { hubungan } \\
\text { tanpa } \\
\text { status }\end{array}$ & $\begin{array}{l}\text { berhubungan tanpa } \\
\text { kejelasan } \\
\text { "aku sama dia hts } \\
\text { bu." }\end{array}$ \\
\hline 12. & W & Saya & $\begin{array}{l}\text { saya (gue) } \\
\text { "w caw" }\end{array}$ \\
\hline 13. & Oc & Oke & $\begin{array}{l}\text { Oke } \\
\text { "oc!" }\end{array}$ \\
\hline
\end{tabular}

Tiga belas kosakata tersebut terbentuk karena singkatan/ akronim dari kata. Seperti TP akronim dari tebar pesona mempunyai makna cari perhatian kepada lawan jenis. Kosakata ini digunakan untuk ungkapan menggoda kepada temannya. $G C$ akronim dari gerak cepat mempunyai makna bergerak dengan cepat. Kosakata ini digunakan untuk mengunggkapkan kekesalan. $B M$ akronim dari banyak mau mempunyai makna seseorang yang mempunyai 
keinginan yang banyak. Kosakata ini digunakan untuk mengungkapkan kekesalan. $J B$ akronim dari join bareng mempunyai makna gabung bersama-sama. Kosakata ini digunakan untuk ungkapan mengajak. WTF akronim dari bahasa asing what the fuck yang mempunyai makna sialan. Kosakata ini digunakan untuk mengungkapkan kekesalan kepada kawan.Berdasarkan penggunaan emosialnya pada bentuk kosakata dengan singkatan mempunyai 1 kata mengungkapkan amarah, 1 kata mengungkapkan kesedihan, 6 kata menujukkan kenikmatan, 1 kata menunjukkan terkejut, 3 kata menujukkan jengkel, 1 kata menunjukkan malu, dan tidak ada kosakata yang meunjukan rasa takut dan cinta.

Tabel 4 Kosakata dengan Pemenggalan

\begin{tabular}{llll} 
No. & Kosakata & \multicolumn{2}{c}{ Keterangan } \\
\cline { 3 - 4 } 1. & Lehakata & \multicolumn{1}{c}{$\begin{array}{c}\text { Makna dan } \\
\text { Pahasa } \\
\text { Pndonesia } \\
\text { Boleh }\end{array}$} & $\begin{array}{l}\text { Pemaianna } \\
\text { boleh } \\
\text { "leh uga" }\end{array}$ \\
2. & Jan & Jangan & $\begin{array}{l}\text { Jangan } \\
\text { "jan gitu dongs" }\end{array}$ \\
3. & Tar & Sebentar & $\begin{array}{l}\text { Sebentar } \\
\text { "tar gue makan" }\end{array}$ \\
4. & Sa & Bisa & $\begin{array}{l}\text { Bisa } \\
\text { "sa aja nih" }\end{array}$ \\
5. & Dah & Sudah & $\begin{array}{l}\text { Sudah } \\
\text { "dah balik" }\end{array}$ \\
6. & Uga & Juga & $\begin{array}{l}\text { Juga } \\
\text { "w ikut uga dong" }\end{array}$ \\
7. & Doku & Uang & $\begin{array}{l}\text { Uang } \\
\text { "gak bawa doku" }\end{array}$ \\
8. & Lau & kamu & $\begin{array}{l}\text { Kamu } \\
\text { "lau kemana?" }\end{array}$ \\
9. & Njir & umpatan & $\begin{array}{l}\text { umpatan kasar } \\
\text { "njir dia juara" }\end{array}$ \\
10. & Shiit & kasar & "shiit ambil aja" \\
\hline
\end{tabular}

Sepuluh kosakata dengan pemenggalan boleh, jangan, sebentar, bisa, sudah, juga, uang, kamu, dan umpatan kasar. Kosakata tersebut terbentuk diambil suku katanya. Seperti leh berasal dari kosakata boleh menjadi leh suku kata yang diambil merupakan suku kata ke dua. Berdasarkan penggunaan emosialnya pada bentuk kosakata dengan pemenggalan yaitu satu kata mengungkapkan amarah, dua kata mengungkapkan rasa takut, enam kata mengungkapkan kenikmatan, satu kata mengungkapkan terkejut dan belum ditemukan kosakata mengungkapkan kesedihan, cinta, jengkel dan malu. 
Siswa- siswi kelas XI pada termasuk generasi millenial. Generasi ini selalu mencari hal yang baru, mereka tidak bisa lepas dari gawai. Walaupun mereka duduk berdekatan mereka lebih cendrung mengirim pesan dengan gawai. Pada percakapan keseharian mereka kerap menggunakan bahasa daerah yang dikolaborasikan dengan bahasa Indonesia atau bahasa indonesia yang dikolaborasikan dengan bahasa asing. Ragam bahasa yang digunakan dalam percakapan sehari-hari merupakan ragam bahasa lisan dan tulis. Mereka menganggap jika menggunakan bahasa millenial, akan terlihat gaul, mudah akrab dengan kawan, lebih mudah dipahami jika dibandingkan dengan mereka menggunakan bahasa Indonesia dalam percakapan.

Pada angket daring diperoleh siswa-siswi kelas XI SMAN 15 Kabupaten Tangerang tahun pelajaran 2019/2020 berjumlah 216 siswa. Sebanyak 162 siswa atau 75\% menggunakan 5 kosakata yang paling sering diucapkan seperti; kuy, anjay, ashiyaap, mantaps djiwa, dan mantul. Sedangkan 54 siswa atau 25\% jarang sekali menggunakan kosakata tersebut. Tidak semua siswa-siswi kelas XI menggunakan bahasa millenial dalam percakapan sehari-hari karena masih ada siswa yang menggunakan bahasa daerah (Tangerang) dalam percakapan sehari-hari. Adapun beberapa kosakata yang dipadu padankan dengan bahasa milenial seperti "kuy ka imah aing" bermakna ayo ke rumah saya. Sedangkan pengelompokan emosi dalam golongan besar yaitu 6 kosakata menunjukan amarah, 2 kosakata menujukkan kesedihan, 9 kosakata menujukkan rasa takut, 41 menujukkan kenikmatan, 9 kosakata menujukkan cinta, 9 kosakata menunjukkan terkejut, 22 kosakata menujukkan jengkel, dan 4 kosakata menujukkan malu.

\section{E. KESIMPULAN}

Bahasa Indonesia pada ragam bahasa millenial yang ditemukan dalam percakapan para anggota group Pramuka Libelta dan Flascheetos dapat dilihat berdasarkan pola pembentuknya. Hasil pengumpulan data ditemukan 102 kosakata slang atau bahasa millenial. Terdiri atas analisis kosakata slang/bahasa millenial ini berdasarkan bentuk kata dasar sebanyak 45 kosakata, bentuk frasa sebanyak 34 kosakata, kosakata dengan singkatan sebanyak 13 kosakata, dan kosakata dengan pemenggalan sebanyak 10 kosakata.

Sebanyak 162 siswa atau 75\% menggunakan 5 kosakata yang paling sering diucapkan seperti; kuy, anjay, ashiyaap, mantaps djiwa, dan mantul. Sedangkan 54 siswa atau 25\% jarang sekali menggunakan kosakata tersebut.Oleh sebab itu anggota group Pramuka Libelta dan Flascheetos lebih sering menggunakan istilah baru yang berlatarbelakang bahasa asing dibandingkan kosakata bahasa Indonesia. Hal ini dibuktikan berdasarkan 
penelitian yang hampir seluruhnya merupakan serapan bahasa asing atau dikenal dengan fenomena xenoglosofilia.

Fenomena ini menggunakan kosakata yang aneh dan asing. Sebagian besar siswasiswi kelas XI jarang menggunakan bahasa millenial karena mayoritas siswa-siswi kelas XI merupakan anak asli Tangerang yang masih menggunakan bahasa daerah Tangerang. Mereka beranggapan jika menggunakan bahasa daerah lebih dekat dan lebih terasa kekeluargaannya. Mereka menggunakan bahasa millenial pada media sosial.Sedangkan pengelompokan emosi dalam golongan besar yaitu 6 kosakata menunjukan amarah, 2 kosakata menujukkan kesedihan, 9 kosakata menujukkan rasa takut, 41 menujukkan kenikmatan, 9 kosakata menujukkan cinta, 9 kosakata menunjukkan terkejut, 22 kosakata menujukkan jengkel, dan 4 kosakata menujukkan malu.

\section{F. SARAN}

Perkembangan zaman saat ini memberikan dampak positif dan negatif pada bahasa Indonesia. Dampak positif dari perkembangan zaman, perbendaharaan kosakata bahasa Indonesia semakin bertambah, dan alangkah baiknya jika kosakata tersebut dijadikan kamus bahasa millenial sedangkan dampak negatifnya generasi muda lebih senang menggunakan bahasa millenial dibandingkan bahasa Indonesia yang sesuai dengan PUEBI.

\section{DAFTAR PUSTAKA}

Anjani, Fullaikhah, 2018, Pengaruh Media Sosial dan Eksistensi Bahasa Indonesia di Era Milenial, https://osf.io/preprints/inarxiv/jwbfm/

Brown, H Douglas. 2008. Prinsip Pembelajaran dan Pengajaran Bahasa, diterjemahkan oleh Noor dan Yusi Avianto., Kedutaan Besar Amerika Serikat, Jakarta.

Chaer. 2009. Leksikologi dan Leksiografi Indonesia. Jakarta : Rineka Cipta

Chaer, Abdul dan Leoni Agustina. 2010. Sosiolinguistik. Jakarta: Rineka Cipta

Goleman, Daniel. 1998. Emotional Intelligence. Jakarta : PT Gramedia Pustaka Utama

Lanin, Ivan. 2019. Xenoglosofilia: Kenapa harus Nginggris?. Jakarta : PT Kompas Media Nusantara

Putri, Nimas Permata, 2017, Eksistensi Bahasa Indonesia pada Generasi Millenial,Widyabastra. Nomor 1,05, 45-49; http://ejournal.unipma.ac.id/index.php/widyabastra/article/view/1891/1418

Keraf, Gorys. 2010. Diksi dan Gaya Bahasa. Jakarta : PT Gramedia Pustaka Utama

Saputro, Muhammad Yusuf, 2019, Perencanaan Bahasa Indonesia di Era Digital pada Generasi Milenial, 1, 2, 34-42, Pesona : Pekan Seminar Nasional Pendidikan Bahasa dan Sastra Indonesia; https://journal.uhamka.ac.id/index.php/pesona/article/view/3770

Soedjito dan Djoko Saryono. 2011. Kosakata Bahasa Indonesia. Malang : Aditya Media Publishing 